\title{
保全管理システムの構築とその活用例
}

日本製紙株式会社 勇払工場工務部 浜 田 知 明

\section{The Design of Maintenance Management Software System and Examples of Its Utilization}

\section{Tomoaki Hamada}

Nippon Paper Industries. Yufutsu Mill

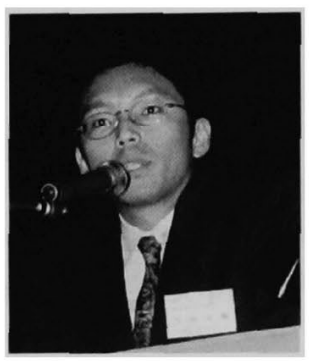

In order to improve the problems in our factory working environment such as decrepit equipment, a downward trend in profitability, and ineffectiveness in the teamwork structure, we introduced 'TPM' activity in 1986 . We have tried to create a maintenance planning system to reduce equipment trouble to a minimum or remove it completely.

Furthermore, we have improved the information management system. because we considered it an important positive step to promote 'TRY' activity. We designed and made use of a maintenance management software system to obtain improvements in production efficiency and the stabilization of the equipment in the factory. We report the progress and the utilization examples that we designed and used for our maintenance management software system.

分類：V、計装・制御システム， Z 工場設計・工場管理（防災・安全含む）

\section{1.はじめに}

1986 年, 設備の老朽化・収益性の低下傾向・小集 団活動のマンネリ化等様々な工場を取り巻く環境の中 で，体質の改善を行うためにTPM 活動を取り入れた。 TPM を工場一丸となって押し進め, 自分達の物に仕 上げることを目的に TRY (Total Refreshment of Yufutsu Mill）と名を改め活動を展開してきた。その 中で, 自分たちの役割でもある「設備の故障や不良を” ゼロ”にしロスをなくす」を主軸に揭げ，計画保全体 制づくりの確立を進めてきた。

TRY 活動を積極的に推進するステップの一つとし て，情報管理体制づくりが重要と考え整備を行い，工 場の生産効率の向上と設備の安定化を図るべく保全管 理システムを構築し運用して来たのでその経過と活用
例を報告する。

\section{1 活動への取り組み}

体質改善を柱にスタートした TRY 活動だが, 電装 課も同活動に参加するため計画保全活動マスタープラ ンを揭示, 有効的な保全計画を進めるに当たり，フェ 一ス展開方式を採用し 4 フェーズ 6 ステップの構図に 乗り取り組みを行ってきた（表 1)。 そのうちの第 3 ステップ目に「情報管理体制づくり」 を位置づけ，情報管理に不可欠なパソコンを駆使する ことで目的の早期達成と保全管理システムの確実な運 用を目指した。

\section{2. 従来の管理方法}

\section{1 設備機器台帳による管理}

システム導入前, フィールドに拡散する各機器の情 


捠田知明

表 1 計画保全のマスタープラン

\begin{tabular}{|c|c|c|}
\hline ステップ & 活動 項目 & 活 動 概 要 \\
\hline 第 1 ステップ & 設備評価と現状把握 & $\begin{array}{l}\text { (1) 設備台帳作成 } \\
\text { (2) 設備評価実施：評価基淮作成 } \\
\text { ランク付 PM 設備・PM 部位選定 } \\
\text { (3) 故障ランク定着付及び自主専門保全区分 } \\
\text { (4) … 他 }\end{array}$ \\
\hline 第 2 ステップ & 劣化復元と弱点改善 & $\begin{array}{l}\text { (1) 劣化復元, 基本条件整備 } \\
\text { 自主保全活動支援 } \\
\text { (2) 弱点改善, 寿命延長個別改善 } \\
\text { (3) …. 他 }\end{array}$ \\
\hline 第 3 ステップ & 情報管理体制つ゚くり & $\begin{array}{l}\text { (1) 故障データ管理システム構築 } \\
\text { (2) 設備保全管理システム } \\
\text { (3) 設備予算管理システム }\end{array}$ \\
\hline 第 4 ステップ & 定期保全体制づくり & $\begin{array}{l}\text { (1) 定期保全準備活動 } \\
\text { (2) ….. 他 }\end{array}$ \\
\hline 第 5 ステップ & 予知保全体制づくり & $\begin{array}{l}\text { (1) 設備診断技術導入 } \\
\text { (2) …. 他 }\end{array}$ \\
\hline 第 6 ステップ & 計画保全の評価 & $\begin{array}{l}\text { (1) 計画保全体制の强化 } \\
\text { (2) …… 他 }\end{array}$ \\
\hline $\begin{array}{l}\text { 専門保全 } \\
\text { 教育育成活動 }\end{array}$ & 専門家の育成 & $\begin{array}{l}\text { (1) 課内教育基礎講座 } \\
\text { (2) …… 他 }\end{array}$ \\
\hline
\end{tabular}

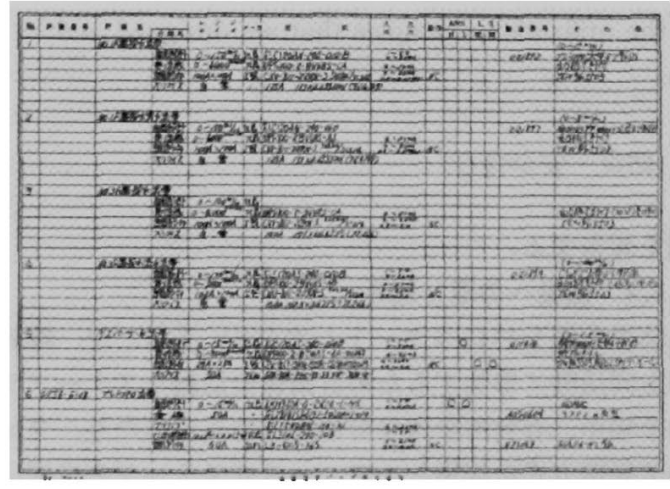

図 1 設備台帳

報は，納入される仕粎書を基にその内容を台帳に記入 していた（図 1)。機器は，頭とその手足となる複数 の計器を持ちループとして一まとめにして管理されて いたが，背番号となる管理番号が各セクション(室別) 毎に付けられていたため重複する番号が存在し，また 番号がないものもあった。また, 台帳は機器納入時の 初期情報しか記載されておらず, 保守や故障の履歷が
追えなかった。

\section{2 計器ループ数の推移}

年々，新設及び改造工事等を経て計器台数が増加す るにつれ，従来の台帳による管理は非効率的であり， 故障への即応性にも欠けることから，一元化（デー夕 ベース化）して管理した方が良い傾向になってきてい るのも事実である(図2)。

\section{3. システムの基本構想}

\section{1 データベース化の必要性}

故障等が発生した場合、その対応及び処置には個人 差があり，そのノウハウは優秀なべテランの経験と勘 で管理されていた部分が多い。近年、抄紙機の高速化 やプラントでの機器の依存度は高く, 故障による停止 は致命的な被害を及はすことになる。そこで,この過 去に蓄積された貴重な技術力や情報を後世に伝達し， 活かされ，全体的に利用するためには，これらをデー タペース化して管理する必要が生まれてきた。こうし て, 計画保全の体制作りと平行して保全管理システム 構築の動きが始まった。 


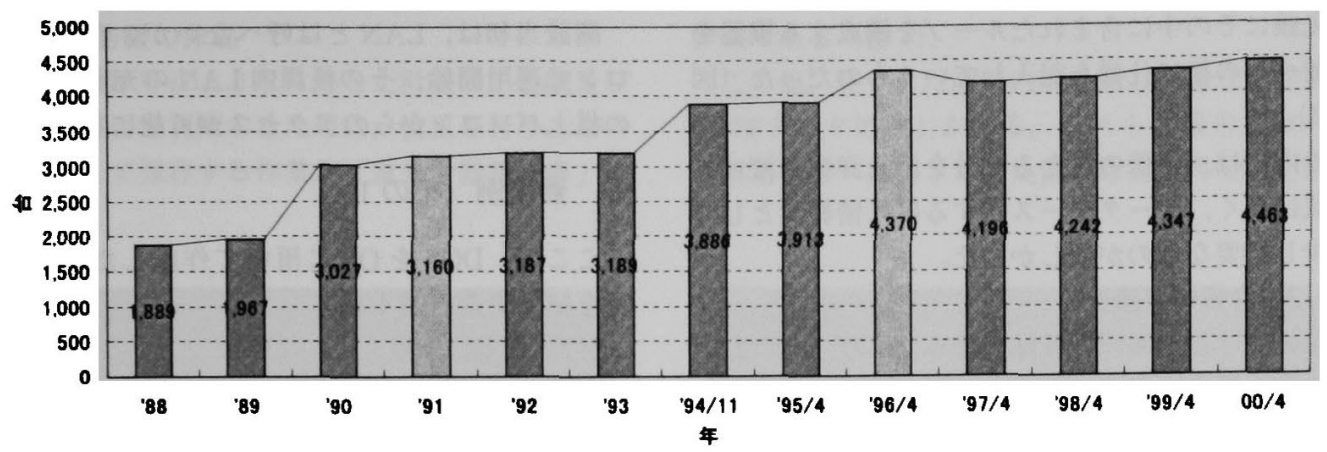

図 2 計装機器台数の推移

\section{2 保全情報の集中管理}

データベース化していく中で, 情報の集中管理にパ ソコンの使用は必須でありこの道具をいかに有効に活 用していくことがポイントになる。つまり，道具の出 来不出来が重要となってくる。設備デー夕の登録・検 索・読み出し等が簡単に行えるよう, 設備台帳管理基 準を新たに作成し、設備を番号及びコード化すること で場内全ての管理を実現する。

\section{3 制御機器への対応}

今日, 制御機器の進歩や各セクション (操業現場) への浸透は急速に進んでおり,これらが故障すると生 産や操業また安全においても多大な損害を与え兼ねな い状況にある。そこで, 制御機器についても各種の情 報（故障周期・故障多発部の把握等）をデータベース 化し，管理することで安定操業の確保と高い信頼性の 維持を狙う(表 2)。

表 2 各セクション毎の制御機器（代表例）

\begin{tabular}{l|c|c}
\hline \multicolumn{1}{c|}{ 抄造 } & 原 動 & 原 質 \\
\hline BM 計 & PLC & PLC \\
欠陥検出器 & DCS & DCS \\
PLC & & \\
DCS & & \\
メカトロ & & \\
\hline
\end{tabular}

\section{4 保全管理の重要性}

壊れたら直すの繰り返しではなく，計画的に管理さ れた保全業務を行うのも主な目的の一つと考える。リ レ一等動的 (機器) 部品は, 故障周期を予知し事前対 処で故障を未然に防ぐことができる。そこで，故障の 頻度や機器固有のメンテナンス周期等を, 収集したデ 一タを元にスケジュール化し保全カレンターにして先 手の保守を目指す。

\section{4. システムの構築}

\section{1 システムの検討}

システムの作成に当たり, 当時発売されていた市販 のソフトの数々を調査し検討した結果, 既製品では当 工場での運用において何れも過不足があった。その他, 下記理由にもよる（表 3)。そこで, 使う以上は快適 なものにしたいが故, 自分達のニーズに合ったシステ ムの構築を行う必要があった。

4.1.1 ソフト作成期間

·構築期間：' 90 年 1 月 ' 90 年 12 月

·制作期間：'91 年 1 月 ' 91 年 11 月

・作成者：1名（専門保全チームを発足）

・運用開始: '91 年 12 月

\section{2 既設台帳からの移し替え}

\subsection{1 台帳の情報量}

以前使用していた台帳は, B 4 サイズの横型で計器

表 3 社内での棈築理由

\begin{tabular}{|c|c|}
\hline 市 販 品 & 由 \\
\hline \multirow{3}{*}{$\begin{array}{l}\text { 自分達のニースに } \\
\text { 合わない }\end{array}$} & ・幅広く対応した一般的なもので，管理に不要な部分が多かった。 \\
\hline & ・ライセンス等の問題で, パソコン台数が増加した場合にソフトの移植が簡単に出来ない。 \\
\hline & $\begin{array}{l}\text { ソフトがユーザーに開放されてなく, 改造や拡張作業に対し，メーカー依頼が必要で且 } \\
\text { つ費用が掛かる。 }\end{array}$ \\
\hline
\end{tabular}




浜田知明

名を先頭にその中に含まれたループを構成する機器を 縦に並べその横に仕様を記入していくものだった（図 1 参照)。

その内容は，代様の主たる部分を記し詳細に渡って の揭載はなく，データベース化するには情報量として もう少し必要なものが欲しかった。

\subsection{2 台帳の再調查}

信頼の置ける情報源の確保が基本であり，そのため に「設備台帳調查用紙」を作成し課員総出でフィール ド調査を行った。調查は，業務の合間を利用し各機器 に取付けられた銘板を読みとり、約 1 年掛けている。 やはり大変だったのは, 制御機器の場合で幾つもの変 換器を有しており，構成品の追跡調査に大きな時間を 費やすことになった。

\section{3 利便性の追求とその整害}

パソコンを用いての情報管理は，その使用形態で 様々な有効因子を生む。代表されるものとして，多人 数での同時利用と, 単語の入力及び登録をキーワード ・コード化することで記載事項の標準化等が挙げられ る。

しかし，その反面，追求の余り使いやすさに整害を 及はすことがないような設計への配虑が必要である。

\subsection{LAN (ネットワーク) の道入}

機器のあらゆる情報をデータベース化し活用するの は良いが，その蓄積された貴重なデータがパソコンの 中に埋没してしまっては価值がない。そこで, 多人数 が同時に使用でき，そして同じレベルの情報収集を可 能とする「情報の共有化」（LAN）の導入を行った。
開設当初は, LAN とは呼べないが 3 台の専用パソ コンで運用開始，その後課内 LAN の充実により各自 の机上パソコンからのアクセスが可能になった（図 3)。

\section{5. 活用例 (その1)}

ここで，DOSを OSに用いて作成した画面の代表 例を紹介する（図 4,5）。

5.1 画面構成

画面の内容及び構成は次の通りである（表 4)。

\section{2 運 用}

\section{2 .1 日常作業}

日毎の業務で発生する故障及び補修作業内容は, 「保 全日次処理」を用いて該当する機器へと登録されてい く。これによって，各種デー夕を逐次蓄えることにな る。

\section{2 .2 保全カレンダ}

主に, BM 計・宿検出器・DCS 等のシステム機 器の定期点検で有効活用している。その他, 計器, 調 節弁の単体においても保全周期を定めスケジュール化 し計画管理している。「保全計画管理」に該当する (図 6)。

\subsection{3 機器マスター入力}

追加・改造工事等で新たに加わる機器は，「機器、 スター入力」で登録を行う。パソコンの利用で，台帳 が嵩張ることなくキー入力で作成が可能であり，また 検索機能により空きのループ番号や機器番号が容易に 素早く割り付けできるようになった。

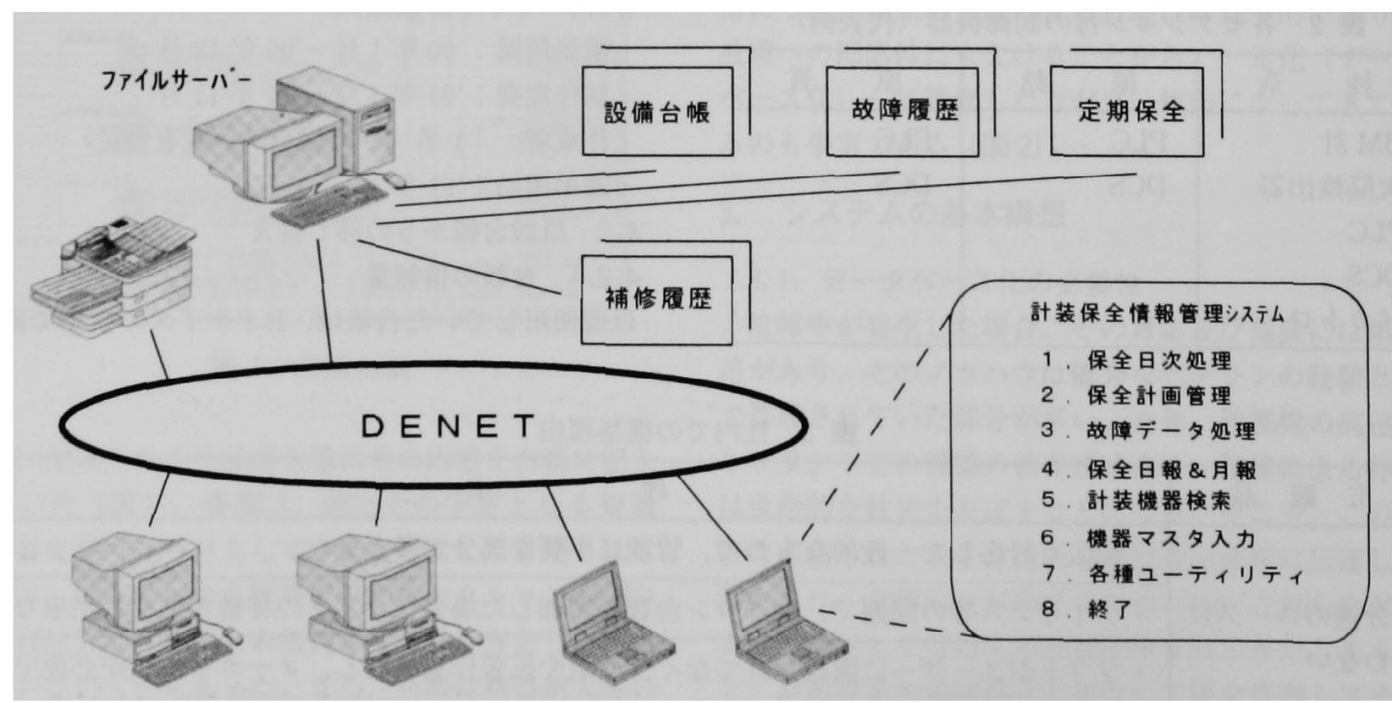

図 3 電装課パソコン LAN（DENET） 


\subsection{4 報告書の作成}

補修及び故障等により取り外した計器は，性能及び 継続使用の可否を判断するために，校正を行う。その 際, 覆歴として保存する作業が「重要計器報告書」の

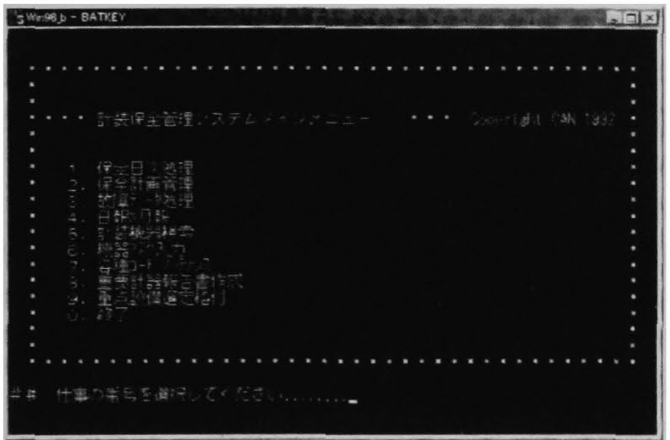

図 4 トップメニュー

\section{作成である（図 7)。}

この他, 発生した故障内容を記し登録及び発行する 「故障データ処理」がある。これらの報告書は, 出力 し関連職場へ提出され，処置の確認と再発防止策に役

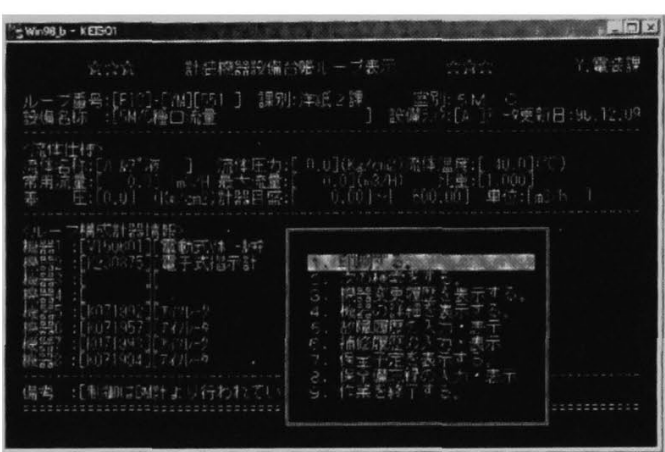

図 5 ループ番号検索

表 4 画面の構成

\begin{tabular}{|c|c|c|}
\hline 主 項 目 & 概 & 副 項 \\
\hline 保全日次処理 & $\begin{array}{l}\text { 日毎の保全作業を支援する。 } \\
\text { 台帳登録された機器の表示, 故障・補修履歴の入力, 機 } \\
\text { 器変更履歴·保全予定の表示·変更等を行う。 }\end{array}$ & $\begin{array}{l}\text { ループ番号検索 } \\
\text { 機器番号検索 (計器) } \\
\text { 機器番号検索（バルブ） } \\
\ldots \ldots . . \quad \text { 他 }\end{array}$ \\
\hline 保全計画管理 & $\begin{array}{l}\text { 補修実績と台帳登録された保全周期によって計算された } \\
\text { 計画日による定期保全処理を行う。 }\end{array}$ & $\begin{array}{l}\text { 定期保全計画（計器） } \\
\text { 定期保全計画（バルブ）} \\
\ldots \ldots . . \quad \text { 他 }\end{array}$ \\
\hline 故障データ処理 & $\begin{array}{l}\text { 日次処理で入力された故障履歴データのメンテナンス及 } \\
\text { び検索を行う。 }\end{array}$ & $\begin{array}{l}\text { 故障履歴一覧 } \\
\text { 故障新規入力 } \\
\text { 故障新規入力 (システム) }\end{array}$ \\
\hline 日報＆月報 & 各種実績データを日毎・月毎に集計し表示, 印刷する。 & \\
\hline 計装機器検索 & 台帳入力された機器を検索・表示・印刷する。 & $\begin{array}{l}\text { ループ検索 } \\
\text { 計器検索 } \\
\text { バルブ検索 } \\
\ldots \ldots . \text { 他 }\end{array}$ \\
\hline 機器マスター入力 & 設備台帳のデータ入力処理を行う。 & $\begin{array}{l}\text { ループ構成 } \\
\text { 計器 } \\
\text { バルプ } \\
\cdots \cdots \text { 他 }\end{array}$ \\
\hline 各種ユーティリティー & $\begin{array}{l}\text { データベース牽引ファイルの再構築, 各種コードデータ } \\
\text { の表示・変更を行う。 }\end{array}$ & \\
\hline 重要計器報告書作成 & $\begin{array}{l}\text { 計器台帳に登録されている計器の重要計器報告書を作成 } \\
\text { する。 }\end{array}$ & $\begin{array}{l}\text { 重要計器報告軎一覧 } \\
\text { 重要計器報告書作成 }\end{array}$ \\
\hline
\end{tabular}




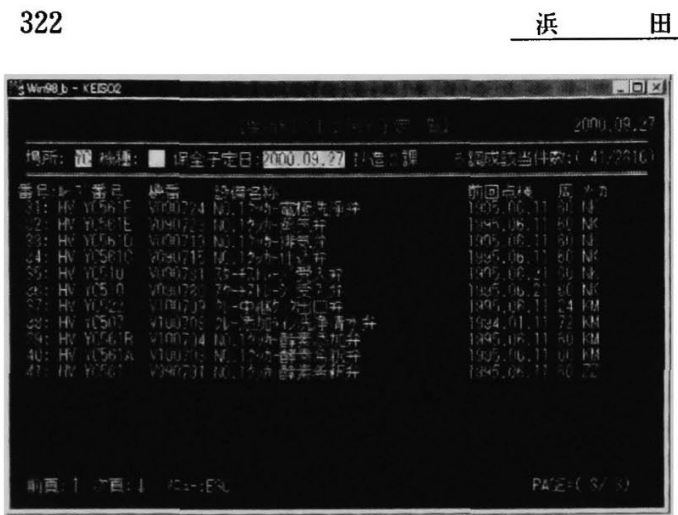

図 6 保全カレンダ（DOS 版）

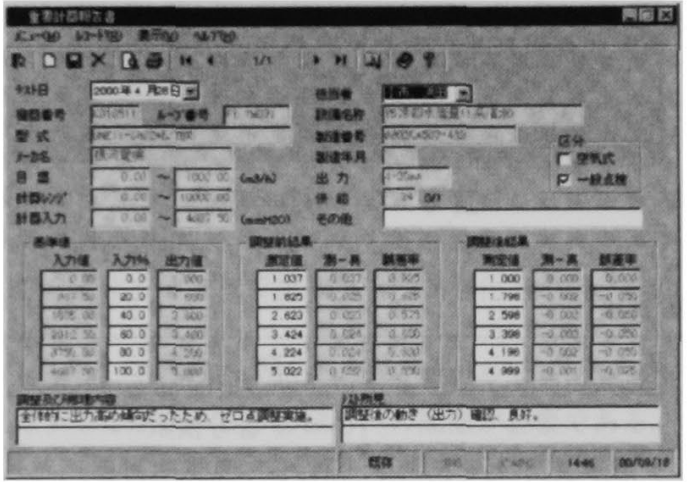

図 7 重要計器報告書
知 明

立っている。

\section{3 機 能拡 充}

Windowsの普及により，更なる有効活用を追求す るため機能拡充を実施, 2 世代目の作成を行った (OS は, visual basic)。

\subsection{1 ソフト作成期間}

・盽築期間：' 99 年 2 月 ' 99 年 3 月

・制作期間：'99 年 4 月 ' 99 年 5 月

- 作成者 : 1 名（期間専従）

・運用開始：'99 年 7 月

\subsection{2 前システム (DOS 版) での不具合点}

情報関連機器の技術革新は目まぐるしく, 我々も流 れに乗り OSをWindowsへと変更した。その際，比 較を行いDOS版でのマイナス面を引き出し構築への 参考とした（表 5)。

\subsection{3 改 良 点}

DOS 版での不自由さ，不満箇所の解消は，OS の変 更でほほ解消でき，快適で操作性の高いシステム作り が可能になった。

\section{6. 活用例（その2）}

システムの基本構成や展開等は, 従来とほほ変更は ない。ここに，Windowsを用いて作成した画面の代 表例を紹介する（図 8,9）。

表 5 DOS版でのマイナス面

\begin{tabular}{|c|c|}
\hline DOS版 & 由 \\
\hline \multirow{4}{*}{ 不自由・不渾な点 } & ·文字や記号の羅列が目立ち, 視認性に劣る。 \\
\hline & ·画面展開が階層になっているため, 画面の横展開が不自由。 \\
\hline & · 1 画面内の情報量に制限があり, 画面の他展開が必要。 \\
\hline & ・マルチ画面が出せず，並べての比較対照が出来ない。 \\
\hline
\end{tabular}

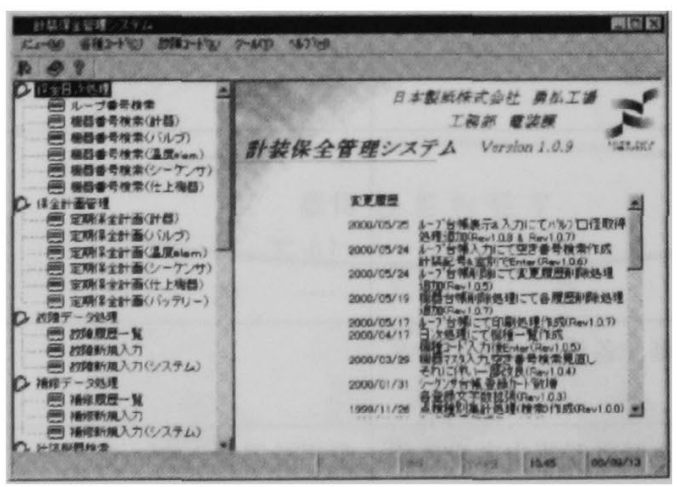

图 8 トップメニュー

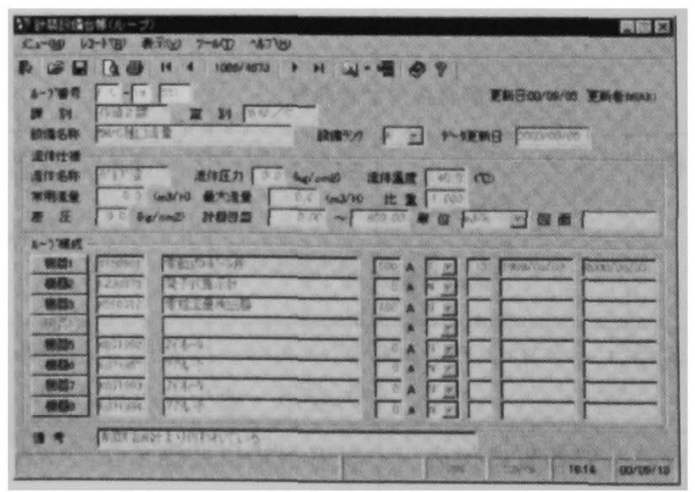

図 9 ループ番号検索 


\section{1 入力の容易性}

OSをWindowsにしたことで，巷に普及し捚染み 深い画面とその操作性により作業の容易性が向上した。 また，事象の登録においても対話形式での入力がより 簡単になった（図 10）。

\section{2 検索 Speed の高速化}

今現在, パソコンは身の回りに浸透し, 道具として 必要不可欠なものの一つである。各自使用のパソコン も業務効率 Upのため適宜更新しており，これにより データベースへの Access Speedの高速化が得られる。

更に, dBASE 形式データを MS Access 形式へ変更 により, Excel 等の汎用ソフトでの利用と編集が可能 となった。

\section{3 保全カレンダの強化}

保全カレンダは, Windows 変更への恩恵を非常に 受けた項目の一つである。画面のスクロール機能によ ク1世代目では無かった各月の列記が可能になり，そ の上で実施予定月欄を記号化することで視認性にも優 れ確実な保全体制が取れるようになった（図 11）。

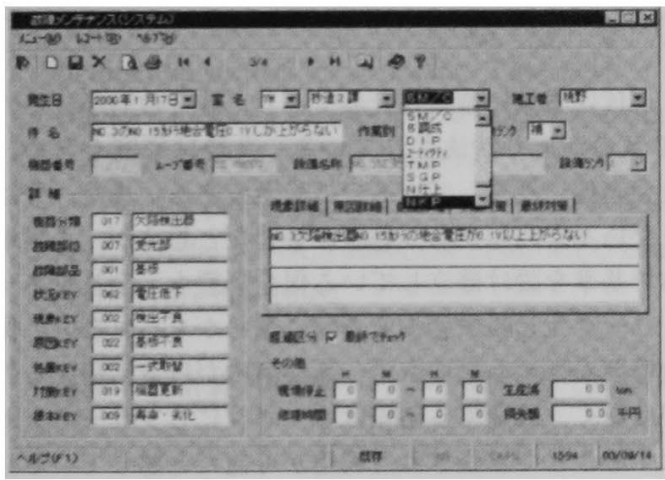

図 10 故障入力画面
7. 効 果

二世代に渡り保全管理システムを構策し，活用して きたことで様々な成果を得ることができた。その幾つ かを挙げる。

\section{1 故障の減少}

あらゆる方面からの情報収集により，データベース 化することで過去の故障処理・対応方法が参照でき， 再発及び類似故障への対応がスムーズになりひいては 故障件数の削減に寄与している（図 12）。

\section{2 情報の共有化}

LANの構築により，一度に多人数がシステムへ接 続出来ることで，日常の業務で各自が収集した情報を 即座にまた適宜参照でき共有化が可能となった。これ で, 補修内容やそのノウハウの伝達の一端が図れるこ とになる。

\section{3 設備保全費の有効利用}

限られた人と補修費で，いかに効果的な保全を実施 するのかも我々に課せられた任務であり，毎年巡って くる課題でもある。

また, システム機器については, 故障の規模に関係 なく生産設備に多大な損害を与え兼ねず，保全カレン

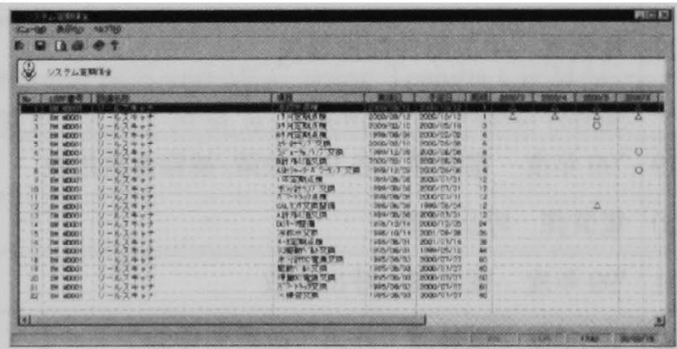

図 11 保全カレンタ（Windows 版）

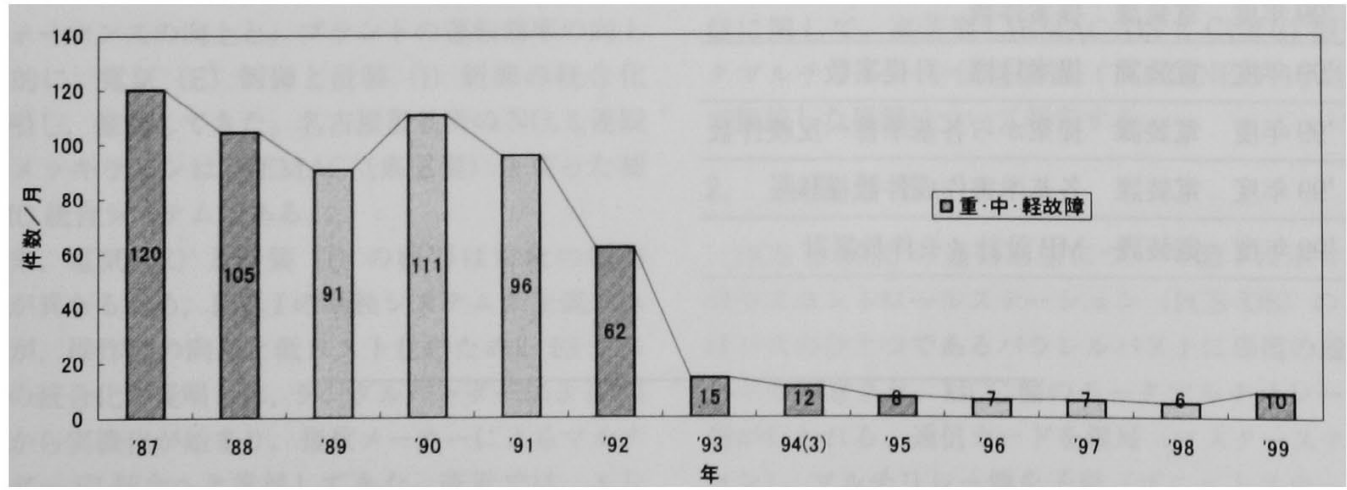

図 12 年度別月平均故障件数 


浜田 知 明

表 6 保全管理年報報告書（タイトル抜粋）

\begin{tabular}{|c|c|}
\hline No. & タイトル名称 \\
\hline & '99 年度 電装課 保全管理 年間報告 \\
\hline 1 & '99 年度 勇払工場 電装機器台数 \\
\hline 2 & 電装機器 課別·年度別台数推移 \\
\hline 3 & 電装機器 年度毎台数推移 \\
\hline 4 & '99 年度 電装課 TRY 故障一覧（電気設備） \\
\hline 5 & '99 年度 電装課 TRY 故障一覧（計装設備） \\
\hline 6 & '99 年度 電装課 TRY ポイント \\
\hline 7 & '99 年度 電装課 重中故障一覧 \\
\hline 8 & '99 年度 電装課 重中軽故障件数推移表 \\
\hline 9 & 年毎／課毎故障ランク別件数推移表 \\
\hline 10 & 年度毎月平均故障件数推移表 \\
\hline 11 & 電装課 故障件数推移 \\
\hline 12 & 電装課 故障件数推移表 \\
\hline 13 & 電装課 重·中・軽別故障件数推移 \\
\hline 14 & 電装課 課別故障件数推移表 \\
\hline 15 & 電装課 年毎重故障停止件数, 停止時間 \\
\hline 16 & 電装課 重故障件数推移表 \\
\hline 17 & 電装課 中故障件数推移表 \\
\hline 18 & 電装課 故障件数推移表 \\
\hline 19 & '99 年度 電装課 各月 故障/補修件数比較 \\
\hline 20 & 電装課 呼出件数 \\
\hline 21 & '99 年度 電装課 呼出件数 \\
\hline 22 & '99 年度 電装課 呼出 故障別件数 \\
\hline 23 & '99 年度 電装課 呼出発生別件数 \\
\hline 24 & '99 年度 電装課 提案件数 \\
\hline 25 & '99 年度 電装課 提案目標 - 月提案数 \\
\hline 26 & '99 年度 電装課 提案から各基準書へ反映件数 \\
\hline 27 & '99 年度 電装課 各基準蕃作成件数推移 \\
\hline 28 & '99 年度 電装課 MP 設計メモ件数累計 \\
\hline
\end{tabular}

多を用い機器供給各社から提案されている故障診断シ ステム等の費用を予算化し効率の良い有効的な定期補 修が可能と言える。

\section{4 保全目標への利用}

収集したデータは，年報として活用しデータ集積に よる保全成果の確認と, 弱点の解析により次年度の保 全目標に設定している（表6）。

\section{8. 今後の方向性}

「故障をゼロにするには？」この問いかけは，TPM 活動における保全担当者への終わりなきテーマであり, その結果が大きく評価される。計画された保全体制を もって，工場全体の総効率の押し上げを担って行きた いと考えており，保全管理システムで得た情報は多方 面で活用し，視点の変更により度毎に活躍の場を広げ て行こうと思う。また，システムの重要度及び活用度 を更に引き上げるには，バージョンアップが必要にな ク，適所での更新を実施して行かなければならない。 管理システムは，設備保全の他に設備予算・予備品 があり今後も三位一体となって「故障削減」と「高い 信頼のある保全」を努めて行きたい。

9. まとめ

現代はまさに情報化社会であり，昨今政府挙げての IT 革命が取り沙汰されている。今後は家庭を含め, 社会全体に浸透してくるのは必至である。また，今は まだ色々な問題があり整理が必要だと思うが，工場単 体で基準を設け確立している保全形態も，全社をネッ トワーク化し規浅化する方向に進むかもしれない。保 全管理システム自体も単一事業所内だけで活用するの ではなく，共通する情報はオーブンにしフリーアクセ スすることで拡張された利用が可能だと感じている。 


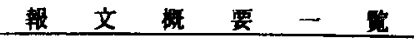

\title{
最近の DCS 更新事例
}

\author{
中越パルプ工菜株式会社 二塚工場製造部 中村 一也
}

二塚工場にDCS を導入してから 20 年近くが経過して, 各工程ではボードレスのCRT オペレーショ ンによる操業を行っている。DCSは，省力化，高効率化を実現したシステムであるが，一旦トラフル が発生すると，直接操莱に影雷する。信頼性維持のために，定期的な保守は行っているものの，設置後 十数年経過したシステムでは, 各部品の劣化, 消耗部品の入手等, 保守上の問題が発生してくる。

本報ではこれらの保守上の問題や，ブラントの增改造に伴ってDCSの更新を行ってきた事例を報告 する。

(本文 32 ページ)

\section{保全管理システムの運用事例}

\author{
王子エンジニアリング株式会社 高橋 㹂二
}

各工場の生産設備の安定操業による生産性向上を図るため, 保全部門（計装，機械，電気）の業務効 率化を促進し，逗正な保全計画を作成して，突発故障のトラフルを娍少させることを目的に保全管理シ ステムの導入に取り組んできた。

今回のシステム導入に当たり，各工場の施設部保全担当者を中心に推進圓任者・担当を選出し全社を あげてスムースな導入が図れる体制をひき，この組織を中心に保全管理業務の改善施策について検討を 行った。

保全管理システムの具体的粠筑は，第 1 期として 96 年度に旧新王子 8 工場に導入，続けて，第 2 期 として 98 年度に旧本州 10 工場に導入しシステム化を行い全社統一システムの運用を行っている。本報 では，保全管理システムの導入について，背景・狙いを活用事例を交えて紹介する

(本文 38 ページ)

\section{保全管理システムの構築とその活用例}

\section{日本製栟株式会社 勇払工場工務部 浜田 知明}

日本製紙勇払工埸では, 1986 年に，新旧設借が混在する他様々な㻴境の中で，体質改善を行い競争力 の強化と品質向上による增収を図るべくTPM 活動を紊入した。この動きは勇払工埸一丸となって押し 進めるもので，個人の意鿁改革も加え実践していった。

電装課としては，使命でもある「設備の故障や不良を“ぜロ”にする」を揭げ，活䡃の一端を担うこ とにした。そのためには，計画的な保全体制づくりが必要と考六計画保全のマスタープランを作成しテ 一ブルに基づき活功を展開していった。活動の一つに情報管理体制づくりの確立があり，効果的に目的 を達成するには，先人が培った传秀な技術力とそのノウハウを確実に継承し生かしていくこと，故障や 補修の内容等の情報を蓄皘してデータベース化し，その集中管理などを全体的に活用できる手段として 保全管理システムの構筑を行った。

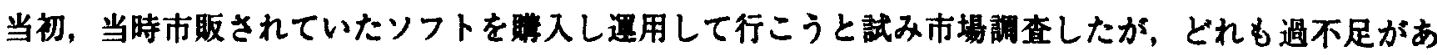
ク自己のニースに合うものがなく，使う以上は快竞で今後のシステム抬張にも柔軟に対応が可能なよう 自分たちで楼等することにした。システムは，作業支援とも位置付けしパソコンの利便性を最大限引き 